\title{
Neoadjuvant Radiotherapy for Soft Tissue Sarcoma
}

\author{
Sam Hajialiloo Sami ${ }^{1}$, Azra Izanloo ${ }^{2}$, Arefpoor Amir Mohamad ${ }^{3}$ and Mirkazemi Masoud ${ }^{* 1}$ \\ ${ }^{1}$ Bone and Joint Reconstruction Research Center, Shafa Orthopedic Hospital, Iran University of Medical Sciences, Tehran, IR Iran. \\ ${ }^{2}$ Razavi Cancer Research Center, Razavi Hospital, Imam Reza International University, Mashhad, Iran \\ ${ }^{3}$ Firrozgar Hospital, Iran University of Medical Sciences, Iran
}

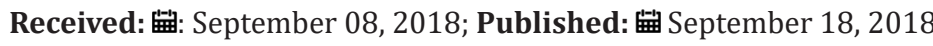

*Corresponding author: Masoud Mirkazemi, Bone and Joint Reconstruction Research Centre, Shafa Orthopaedic Hospital, Iran University of Medical Sciences, Tehran, Iran

\section{Mini Review}

Soft Tissue Sarcoma (STS) is a rare neoplasm that accounts for $1 \%$ of all solid tumors in adults. In 2013, 11410 new cases were diagnosed in adults and children in the United States with 4,390 expected deaths [1]. In more than 50 to $60 \%$ of the cases, limbs are involved and it can have more than 50 histological subtypes [2]. These tumors are invasive and their metastasis risk is high [3]. Today, the treatment of sarcomas often includes a combination of surgery, radiotherapy and chemotherapy [3]. However, there are extensive disputes and challenges regarding the use of chemotherapy and radiotherapy in these patients. Some studies have adopted optional chemotherapy treatment as an adjunct to increase the chance of preserving a limb, but the use of this method has not had a significant effect on overall survival [4].

Other studies have suggested that in patients for whom the tumor cannot be removed completely by surgery, to increase the chance of tumor necrosis considering its high survival, a neoadjuvant chemotherapy treatment with hypofractionated radiotherapy or in some cases adjuvant chemotherapy, depending on the living cells, has been recommended. These methods have been able to improve patient complications and induce a pathologic response [4]. Various protocols have been proposed for radiotherapy of these patients. Radiation protocol is in form of external preoperative radiation therapy and postoperative external radiation therapy or brachy therapy. Each strategy is intended to obtain maximum local control by maintaining limb function $[5,6]$.

In most centres, external radiation therapy is used postoperatively, as it does not require postponing surgery and eliminates the residual disease after surgery. In addition, the pathology sample and surgical margins will be at the disposal of the pathologist for detailed examination $[7,8]$. This method provides the best local control, but since target therapy is not specifically defined, the treatment should be administered with higher dose and greater volume, which leads to physical disability and reduced quality of life [9]. Other morbidities of this treatment includes complications of surgical ulcers and delayed problems such as subcutaneous tissue fibrosis, edema, joint dryness and bone damages like osteoarthritis and fractures [10-12].

For the above reasons, preoperative radiotherapy have received great amount of attention as a new therapeutic approach [13]. In this technique, since the volume of treatment is specified, the field size is contracted [14]. Contrary to postoperative radiotherapy, this technique does not damage the hematopoietic network and since the percentage of hypoxic cells in the tumor margin is lower, it requires a smaller dose of radiation therapy and is therefore associated with improved functional outcomes [15]. Overall, it has been shown that neoadjuvant radiotherapy has a high R0 resection rate for STS patients undergoing surgical resection, and negative surgical margin and pre-or post-operation of RT can improve the overall survival. However, further studies are needed to examine and determine its actual effects.

\section{References}

1. American Cancer Society (2013) Cancer facts and figures, USA.

2. World Health Organization (2002) Pathology and genetics of tumours of soft tissue and bone. In Christopher DM Fletcher, Krishnan Unni K, Fredrik Mertens, Classifications of tumors, ( $3^{\text {rd }}$ edn). IARC, Lyon, France, pp. 427.

3. Eilber FC, Rosen G, Nelson SD, Selch M, Dorey F, et al. (2003) High-grade extremity soft tissue sarcomas: Factors predictive of local recurrence and its effect on morbidity and mortality. Ann Surg 237(2): 218-226.

4. Spencer RM, Aguiar Junior S, Ferreira FO, Stevanato Filho PR, Kupper $\mathrm{BE}$, et al. (2017) Neoadjuvant hypofractionated radiotherapy and chemotherapy in high-grade extremity soft tissue sarcomas: Phase 2 clinical trial protocol. JMIR Res Protoc 6(5): e97.

5. Gingrich AA, Bateni SB, Monjazeb AM, Darrow MA, Thorpe SW, et al. (2017) Neoadjuvant radiotherapy is associated with R0 resection and improved survival for patients with extremity soft tissue sarcoma undergoing surgery: A national cancer database analysis. Ann Surg Oncol 24(11): 3252-3263.

6. Mullen JT, Kobayashi W, Wang JJ, Harmon DC, Choy E, et al. (2012) Longterm follow-up of patients treated with neoadjuvant chemotherapy and radiotherapy for large, extremity soft tissue sarcomas. Cancer 118(15): 3758-3765. 
7. Wolfson $\mathrm{AH}$ (2005) Preoperative vs postoperative radiation therapy for extremity soft tissue sarcoma: controversy and present management Curr Opin Oncol 17(4): 357-360.

8. Panwar U, Sankaye P (2015) Preoperative versus postoperative radiotherapy in extremity soft tissue sarcoma: A changing trend towards preoperative radiotherapy in the UK. Clinical oncology 27(6): 369-370.

9. Nielsen OS, Cummings B, O Sullivan B, Catton C, Bell RS, et al. (1991) Preoperative and postoperative irradiation of soft tissue sarcomas: Effect of radiation field size. Int J Radiat Oncol Biol Phys 21(6): 15951599

10. Zagars GK, Ballo MT, Pisters PW, Pollock RE, Patel SR, et al. (2003) Preoperative vs. postoperative radiation therapy for soft tissue sarcoma: A retrospective comparative evaluation of disease outcome. Int J Radiat Oncol Biol Phys 56(2): 482-488.

11. Davis AM, Sennik S, Griffin AM, Wunder JS, O Sullivan B, et al. (2000) Predictors of functional outcomes following limb salvage surgery for lower-extremity soft tissue sarcoma. J Surg Oncol 73(4): 206-211.

ISSN: 2574-1241

DOI: 10.26717/BJSTR.2018.09.001753

Masoud Mirkazemi. Biomed J Sci \& Tech Res

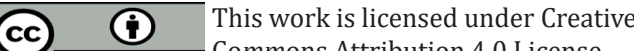

Submission Link: https://biomedres.us/submit-manuscript.php
12. Cahlon O, Spierer M, Brennan MF, Singer S, Alektiar KM (2008) Longterm outcomes in extremity soft tissue sarcoma after a pathologically negative re-resection and without radiotherapy. Cancer 112(12): 27742779.

13. Haas RL, Miah AB, LePechoux C, DeLaney TF, Baldini EH, et al. (2016) Preoperative radiotherapy for extremity soft tissue sarcoma; past, present and future perspectives on dose fractionation regimens and combined modality strategies. Radiother Oncol 119(1): 14-21.

14. Sampath S, Schultheiss TE, Hitchcock YJ, Randall RL, Shrieve DC, et al. (2011) Preoperative versus postoperative radiotherapy in soft-tissue sarcoma: Multi-institutional analysis of 821 patients. Int J Radiat Oncol Biol Phys 81(2): 498-505.

15. Lazarev S, McGee H, Moshier E, Ru M, Demicco EG, et al. (2017) Preoperative vs postoperative radiation therapy in localized soft tissue sarcoma: Nationwide patterns of care and trends in utilization. Pract Radiat Oncol 7(6): e507-e516.

\begin{tabular}{ll} 
BIOMEDICAL & Assets of Publishing with us \\
RESEARCHES & - Global archiving of articles \\
& - Immediate, unrestricted online access \\
\hline
\end{tabular}

